\title{
Long Run Association between Public Debt and Economic Growth in Sri Lanka
}

\author{
Munasinghe Arachchige Achala Munasinghe, A. M. C. P. Attapattu, H. M. N. Padmasiri \\ Department of Business Economics, University of Colombo, Colombo, Sri Lanka \\ Email: achalasajeewa@gmail.com,cpatapattu@gmail.com, nhennayake@gmail.com
}

How to cite this paper: Munasinghe, M.A.A., Attapattu, A.M.C.P. and Padmasiri, H.M.N. (2018) Long Run Association between Public Debt and Economic Growth in Sri Lanka. Modern Economy, 9, 775-789. https://doi.org/10.4236/me.2018.94051

Received: December 4, 2017

Accepted: April 24, 2018

Published: April 27, 2018

Copyright $\odot 2018$ by authors and Scientific Research Publishing Inc. This work is licensed under the Creative Commons Attribution International License (CC BY 4.0).

http://creativecommons.org/licenses/by/4.0/

\section{cc) (i) Open Access}

\begin{abstract}
Sri Lanka is relying heavily on public debt to finance the budget deficit since its independence from British in 1948. Thus, it is much important to investigate the long run of public debt on economic growth of the country for the period 1977 to 2012 using time series data. Sri Lanka introduced fully liberalized economic policy in 1977. The study used domestic debt, external debt and educational expenditure as explanatory variables to determine their effect on GDP in the long run. Long run is estimated by employing Johansen test of cointegration analysis relies on Vector Error Correction Model (VECM). The coefficient of Error Correction Term (ECT) suggests disequilibrium that is corrected at the speed of 58 percent over the each year. Significant ECT is a proof of the existence of long run relationship.
\end{abstract}

\section{Keywords}

External Debt, Domestic Debt, Cointegration, Long Run

\section{Introduction}

Government needs to borrow for two broad categories; macroeconomic purposes such as higher investment, higher consumption (education and health) or to finance transitory balance of payments deficits [to lower nominal interest rates abroad, lack of domestic long-term credit, or to circumvent hard budget constraints] [1].

But it has been observed since 1900; most of the counties in both advanced and emerging category accumulate debt/borrowings mainly for the purpose of financing budget deficits. Situations where advanced economies also happened to depend on the borrowings because of large stock of defense expenditure spent on for world war period in early $20^{\text {th }}$ century and withstand for adverse effects of 
such as the oil prices crisis and debt crisis occurred in 1970-1980. However, for those less debt burdened nations, association of debt seemed to have higher growth rates where emerging countries and less developed countries kept accumulating debt for promoting economic growth due to their limited capacity to promote economic growth and to bridge budget deficits.

Governments prefer accumulation of debt in financing budget deficits because it is an anti-inflationary mechanism unlike printing money or imposing taxes. Although government can use taxes to finance its budget deficit, taxes tend to distort the structure of relative prices, and borrowing, if pushed beyond the carrying capacity of the economy, creates problems of intergenerational equity [2]. "Any attempts to reduce the deficit by raising taxes to intolerable levels or cutting down on capital expenditure are ill-advised as they only jeopardize future growth prospects of the economy" [3]. Therefore, it seems that government uses both the strategies simultaneously. Having accumulated public debt for a longer period and considerable proportion of foreign capital inflows (export income and new credit facilities) used to service debt annually, it is important to ask how public debt may influence economic growth because policy makers need to be aware of the relationship between these when formulating and implementing macroeconomic policies.

As the importance of the study, debt is improving welfare and enhancing growth at moderate level but there is damage from high level of debt [4]. They further say that there is a threshold for debt as a proportion of GDP and the government should keep well below this level and otherwise it will badly influence on economic growth. Accordingly, this paper is important for decision making to address fiscal problems.

\section{Research Issue}

Prior literature has shown a mixed impact of public debt on economic growth. Important point is according to the context those studies are carried out the results are varied thus there is no common agreement. A different political parties governing since the independence have been using debt finance to meet budget deficits.

Financing budget deficit through sources such as printing money, increasing taxes and cutting down government expenditure lead to increase price level of the country which may result in deteriorating living standards of the people [3], therefore in order to balance these adverse effects come through various sources public debt seemed to be playing a significant role in financing fiscal deficit in Sri Lanka. As pointed out by Pathberiya and Wijeweera [5] reasons for greater accumulation of external debt are; investment projects undertaken by the government on the areas such as power and energy, irrigation and agriculture and greater depreciation experienced by Sri Lankan rupee against major currencies. These researchers have paid attention in relation to budget financing and the courses for borrowing debt. However, there is a doubt that whether public debt 
have a significant literature review impact on economic growth in Sri Lanka. Accordingly, researcher has taken this situation the gap as a research issue in the study.

\section{Literature Review}

\subsection{Theoretical Arguments towards Impact of Public Debt on Economic Growth}

\subsubsection{Ricardian Perspective}

This theory was developed by David Ricardo in the nineteenth century. He suggests that when a government tries to stimulate demand by increasing debt-financed government spending, demand remains unchanged. This is because the public will save its excess money in order to pay for future tax increases that will be initiated to pay off the debt.

According to the Ricardian equivalence theory Bernheim [6] stated an increase in the public debt is offset by an increase in the private savings ratio, because individuals take account of the prospect of a future tax increase and a future public spending cut. There by the ultimate impact of public debt on economic growth would be neutral. However, the Ricardian equivalence theory is based on a number of unrealistic assumptions, e.g. that households face no budget constraints and that households take account of an infinite time horizon and non-distorting, lump-sum taxes. Consequently, though an increase in the public debt may lead to a higher private savings ratio that will not be enough to compensate entirely for the decline in national net savings.

Later Harvard professor Robert Barro [7] reexamined Ricardo's ideas into more elaborate versions of the same concept. Also known as "Barro-Ricardo equivalence proposition".

As stated by Buchchan Barro's [8] central emphasis is on demonstrating that, under reasonable conditions which involve overlapping generations of persons with finite lives, taxpayers will capitalize the future obligations that public debt issue embodies. To the extent that this capitalization occurs government bonds do not add to the perceived net wealth of the economy. From this Barro infers that the substitution of debt for tax finance will exert no expansionary effect on total spending.

\subsubsection{Keynesian Paradigm}

For more than eight decades, famed economist John Maynard Keynes has been the subject of much discussion and debate while the neoclassical and Ricardian schools of thoughts focus on the long run effects and Keynesian view emphasizes the short run effects [6].

As highlighted by Bernheim [6] Keynes argument based on two assumptions. First, there is a possibility of being some economic resources are unemployed. Second, aggregate consumption is very sensitive to changes in disposable income due to large number of liquidity constrained or myopic individuals in the society. 
Keynes theories on economics ignored the basic laws of supply and demand. However, unlike economists before to Keynes, he argued that demand drives supply. In Keynes view, insufficient demand leads to excess supply of goods, which leads to cease production. Ultimately, weak demand leads to a downward trend in unemployment due to downsizing, and then poverty and even depression of economy. In order to remedy this weak/insufficient demand Keynes doctrine was to artificially stimulate demand by increasing government spending or cutting taxes, which then encourages the public to increase its spending as a result. The argument was to cause either increase government or the public spending to stimulate the under active economy

(http://www.maynardkeynes.org/).

According to Keynes these objective of stimulating economy could be achieved through fiscal policy; expending public spending or tax cuts. Out of these two options Keynes concerned on cutting taxes rather than increasing expenditure to boost the underactive economy. Keynes favored government deficit spending through increasing expenditure only to handle economic depressions, not to uptrend low levels of unemployment created through weak demand. He also favored creating surplus budgets to eliminate government debt when the economy is overly active. Thus, Keynes was flexible for both situations concerning short term. (http://www.maynardkeynes.org/).

The primary concern about large government debt for financing deficit would lead inflation. Notably, Keynes advised that inflation could be treated with the help of budget surpluses and/or restrictive monetary policy. Though Keynes argued for budget deficits to stimulate demand, he also advocated for subsequent budget surpluses to eradicate debt [6].

\subsection{Empirical Evidence towards Impact of Public Debt on Economic Growth}

Positive effects of public debt relate to the fact that in resource-starved economies debt financing if done properly leads to higher growth and adds to their capacity to service and repay external and internal debt [2]. Chowdhury [9] stated that as far as the relationship of public external debt of an economy and economic growth is concerned, a reasonable level of borrowing is likely to enhance economic growth through capital accumulation and productivity growth [2]. Burnside (2000) pointed out at the initial phase of development countries have small capital stocks and the investment opportunities are also limited, therefore external borrowings for productive investment provide macroeconomic stability. Paudel and Perera [10] highlighted that foreign debt in developing countries can be used to acquire technology and other factors of production to increase employment opportunities and national productivity. Egbetunde [11] point out public debt and economic growth are positively related if the government is sincere with the loan obtained and use it for the development of the country rather than channel the funds to their personal interests. 
In contrast, Shah and Pervin [12] remarked if the rate of return from public debt is higher than the debt service payment rate, it has greater possibility of affecting positively on economy and vice versa.

Barik [13] in contrast to direct relationship of public debt and economic growth empirically examined indirect influence of public debt on economic growth through its impact on investment in India for the period of 1981-2011 and regression results indicated that public debt positively affects economic growth; one percent point increase in debt is associated with an increase in real GDP of around 0.08 percentage point per year. Based on the results concludes that government debt has made a significant contribution to the economic growth not only directly but also indirectly via investment and hence debts have positive effects in developing economies because of that funds are allocated for investment purposes.

As per debt guide (2013); debt liabilities owed by residents to residents of same economy are domestic debt. Reinhart, Rogoff, and Savastano [14] state all debt liabilities of a government that are issued under and subject to national jurisdiction, regardless of the nationality of the of the creditor where terms of the debt contracts may be market determinate or set unilaterally by the government.

Debt guide (2013); debt liabilities owed by residents to nonresidents are external debt. Reinhart, et al. [14] define external debt as total liabilities of a country with foreign creditors both public and private. Creditors often determine all the terms of the debt contracts, which are normally subject to the jurisdiction of the foreign creditors or, for multilateral credits, to international law. Shah and Pervin [12] describe external debt as the total public and private debt owed to nonresidents repayable in foreign currency, goods or service.

In most literature evidence public debt is classified as sum of external debt and domestic debt [2] [13]. Total debt liabilities of a government with both domestic and foreign creditors where "government" normally comprises the central administration, provincial and local governments, and all the entities that borrow with an explicit government guarantee are defined as total public debt [14].

Basically budget deficits are financed by; printing money, foreign borrowings, domestic borrowings and running down foreign exchange reserves [15]. In this nature (where public debt works in line with the budget deficits), Efthimiadis and Tsintzos [16] highlighted that public debt and economic growth gained much attention over the recent decades as many countries have experienced lasting budget deficits which lead to sharp increases in Debt-to-GDP ratios, and for many, a large share of external debt.

\section{Methodology}

\subsection{Unit Root Test}

When conducting time series studies prior literature has obliged to check univariate time series of variable by using a unit root test in each series before esti- 
mating any equation. It is considered as a problem if there is a unit root because particular series considered being non-stationary. Granger and Newbold [17] asserted that estimations based on non-stationary variables may lead to spurious results which produce high $\mathrm{R}^{2}$ value and $\mathrm{t}$ statistics, but without any coherent economic meaning. Further they stated that in order to series to be stationary expected mean and variance of the variables must be stable over the period and cross-observation relations should not be remained. But the inherent feature of time series data used in such economic variables is to comprise of this non-stationary problem. Because there is a greater possibility of values in time series data are affected by temporary shocks occurred in previous time period, and such shocks would cause damages to remain the stationarity of entire time series appearing as permanent shocks. Variables which are non-stationary considered as unit root. Since, this study entirely a macroeconomic study and there is such a possibility of these variables containing non-stationary problem.

In order to perform the unit root test, this study has adopted the Augmented Dickey-Fuller (ADF) test of checking unit root because ADF unit root testing procedure is well established in the literature. Three different specifications of ADF are available. The first include both trend and intercept, second includes intercept without trend term, third exclude both trend and constant i.e. none. In this study first specification is adopted to test the null hypothesis; the series contain a unit root. Then the results are analyzed whether the variables are stationary at level or at $1^{\text {st }}$ difference I (1) at 5 per cent significance level. If all the variables contain unit root at level I (0) and stationary at $1^{\text {st }}$ difference considered as variables are integrated in same order. Therefore it is expected such integrated variables are cointegrated. Thus, unit root test satisfies the requirement to perform a cointegration analysis to examine whether there is a long run association from independent variables to the dependent variable.

\subsection{Lag Length Criterion}

It is also important to select appropriate lag length. Harris and Sollis (2003) stated [18] two few lags would adversely affect the size of the test while too many lags may reduce the power of the test. The study expects to use Vector Auto Regressive (VAR) Lag Order Selection Criteria to select the optimal lag length. Under that, using Akaike information criterion (AIC), Schwarz information criterion (SIC), Hannan-Quinn information criterion (HQ), Sequential modified LR test statistic (LR) lag length and Final prediction error (FPE) are selected. The lag length provided by most of the information criterion is utilized in the study.

\subsection{Cointegration Analysis}

After checking whether all the time series macro-economic variables deployed are integrated in the same order, subsequently the study test cointegration among the variables (Domestic Debt (DD), External Debt (ED), Educational expenditure (Edu) and Gross Domestic Production (GDP)). 
The objective of adopting the cointegration technique is to determine the long run association among macroeconomic variables in the model. Previous authors who adopted Cunningham's [19] debt inclusive growth model for examining the impact of debt on economic growth have used cointegration technique to examine the long run relationship/association [2] [12] [20] [21] [22].

Two main cointegration techniques are generally used; Engle and Granger [23], technique and Johansen and Juselius [24]. According to Karagol [20], the procedure suggested by Engle and Granger [23] contains a set of shortcomings such as unrealistic assumptions (cointegrating vectors are unique), testing procedure of cointegration is not a straightforward procedure when the vectors are not unique and it examines only the dominant cointegrating vector between series but the procedure developed by Johansen and Juselius [24] have overcome the weaknesses of the model developed Engle and Granger [23]. Procedure suggested by Johansen and Juselius [24] basically depends on direct investigation of cointegration in the Vector Autoregressive (VAR) representation and it allows for maximum likelihood estimators of the unconstrained cointegration vectors.

In order to determine the number of cointegrating vectors, this procedure contains two different likelihood ratio tests to decide the value of cointegrating vector, namely trace statistics test and Maximum Eigenvalue test statistics. It is expected to employ both these ratios to determine the number of cointegration equations. Trace test formulated as;

$$
L R=T \sum_{i=r+1}^{n} \ln \left(1-\lambda_{i}\right)
$$

Trace statistics test is combined test where null hypothesis is that the number of cointegrating vectors are less than or equal to $r$ opposed to alternative hypothesis that there are more than $r$ cointegrating vectors. And the Maximum Eigenvalue test statistics is;

$$
L R=T \ln \left(1-\lambda_{r+1}\right)
$$

Here, null hypothesis is, number of cointegrating equations is $r$ against the alternative hypothesis of $r+1$ where Maximum Eigenvalue test conducts separate tests for each Eigenvalue. Thus, the null hypothesis was tested sequentially from low to high values of $r$. In this study, researcher expects to employ both these ratios to determine the number of cointegration equations and either one which provide better result is considered.

But the cointegrating vectors produced by Johansen test of cointegration still contain unit root and thus the results are spurious. Therefore as the next step of Johansen test of cointegration error terms of each cointegration vector should be corrected and to perform this estimation study adopts Vector Error Correction Model.

\subsection{Vector Error Correction Model (VECM)}

As stated by Johansen and Juselius [24] VECM model has two implications. 
First, it provides the mechanism for which validating the estimations of Johansen test of cointegration. Since variables in cointegration model contain unit root, hence results are considered to be spurious. Therefore VECM model focuses on correcting the error term of cointegration vectors in order to validate the long run association results provided by Johansen test of cointegration. The guideline used by the founders is to have a negative sign for the Error Correction Term (ECT) which is statistically significant at 5 percent level. Therefore correctly singed and significant ECT is expected to confirm/validate the long run relationship form DD, ED and EDU to GDP.

Second implication is; Johansen and Juselius [24] stated if there is a cointegration relationship or equilibrium (which implies long run association) among non-stationary variables, in order to identify short run dynamics, data must be tested and represented under the mechanism of Error-Correction. VECM model explains the short run dynamics or the short run disequilibrium of the model. Although Cointegration test confirms there is long run equilibrium between the variables in the model, they might not be at equilibrium in short run. This is because transitory shocks deviate from the equilibrium in the short run. The coefficient value of the ECT provides information to identify the pace at which the disequilibrium is corrected i.e. speed of adjustment towards the long run equilibrium after a short run shock.

In VECM, variables are expressed in first difference (except for ECT) and thereby non-stationary problem is eliminated. Therefore model used in this study included in the following error correction Thus, vector error correction equation for the model deployed of the study will be;

$$
\begin{aligned}
\ln \mathrm{GDP}_{t}=\beta_{0}+\sum_{i=1}^{n} & \beta_{1} \ln \mathrm{GDP}_{t-i}+\sum_{i=1}^{n} \beta_{2} \mathrm{DD}_{t-i}+\sum_{i=1}^{n} \beta_{3} \mathrm{ED}_{t-i}+\sum_{i=1}^{n} \beta_{4} \mathrm{EDU}_{t-i}+\varepsilon_{t} \\
\ln \mathrm{GDP}_{t}= & \beta_{0}+\sum_{i=1}^{n} \beta_{1} \Delta \ln \mathrm{GDP}_{t-i}+\sum_{i=1}^{n} \beta_{2} \Delta \mathrm{DD}_{t-i}+\sum_{i=1}^{n} \beta_{3} \Delta \mathrm{ED}_{t-i} \\
& +\sum_{i=1}^{n} \beta_{4} \Delta \mathrm{EDU}_{t-i}+\propto \mathrm{EC}_{t-1}+\varepsilon_{t}
\end{aligned}
$$

where,

$\operatorname{lnGDP} ;$ Per capita GDP in natural logarithmic form;

DD: Domestic Debt as a percentage of GDP;

ED: External Debt as a percentage of GDP;

EDU: (Proxy variable for human capital) Annual education expenditure;

$\varepsilon_{i}$ : Random error term;

EC: Error correction term.

Researcher applied Equations ((3) and (4)) in the analysis which represents vector auto regression and Vector error correction models respectively.

\section{Data Presentation and Analysis}

\subsection{Source of the Data}

Main source of the debt data are obtained from the publications of Public Debt 
Department of Central Bank of Sri Lanka (CBSL). The reliability of the publication "Public Debt Department in Sri Lanka, Performance in 2012 and Strategies for 2013 and beyond" for debt data is high because CBSL remains the responsibility of managing public debt in Sri Lanka under the Monetary Law Act No. 58 of 1949. Education Expenditure (proxy variable for Human Capital) is acquired from the publications of Census and Statistic Department of Sri Lanka. Researcher used annual data in the study.

\subsection{Result for Unit Root Test}

Augmented Dickey Fuller (ADF) unit root analysis has been applied to test the stationary of data (Table 1). Probabilities at level are insignificant and the variables are non-stationary. They are stationary at first difference as the $\mathrm{P}$ values are significant. Therefore, all the variables are none stationary at level and stationary at first difference. These results indicate that they are I (1) variables. Accordingly; vector error correction model can be applied to determine the long run association. Graphical presentations of data are provided by Figure 1 and

Table 1. Unit root test results.

\begin{tabular}{ccc}
\hline Variables & At level & At first difference \\
\hline GDP & 0.3095 & $0.0082^{* * *}$ \\
DD & 0.4492 & $0.0006^{* * *}$ \\
ED & 0.2042 & $0.0000^{* * *}$ \\
Edu. & 0.9999 & $0.0172^{* *}$ \\
\hline
\end{tabular}

Note: ${ }^{* * *}$ and ${ }^{* *}$ indicate statistically significant at $1 \%$ level and $5 \%$ level respectively.

DD

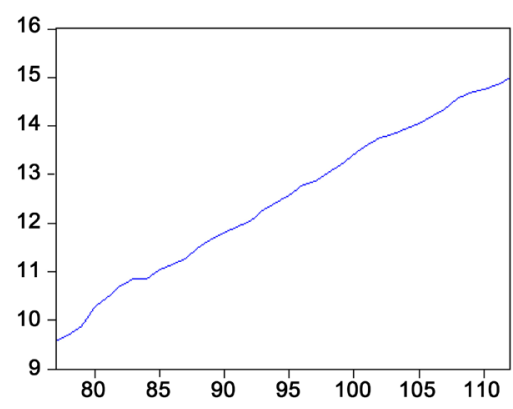

EDU

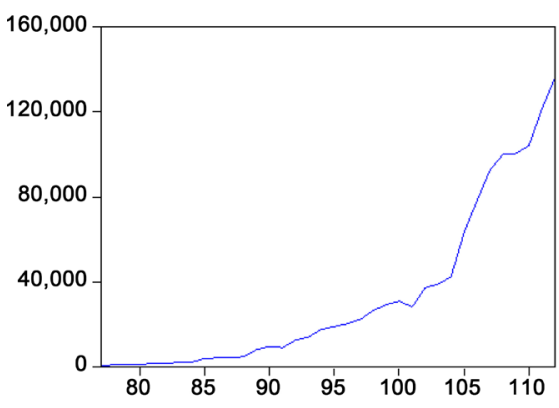

ED

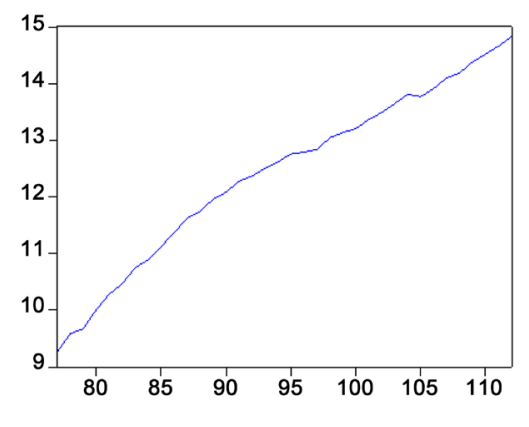

GDP

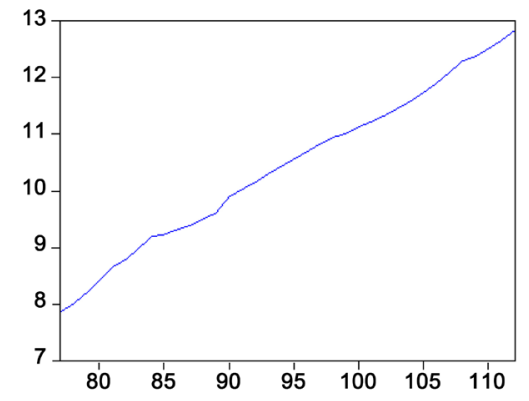

Figure 1. Line graphs of the data. 
they are having trend.

\subsection{Optimal Lag Length Selection}

According to the Schwarz information criterion (SC), and Hannanquinn information criterion (HQ), there is one lag length (Table 2). Akaike information criterion (AIC), Final prediction error (FPE) and Sequential modified LR test statistics (LR) represent three lag lengths. As many criteria recommend three lag lengths, researcher applied three in restricted VAR.

\subsection{Results from the Cointegration Analysis}

Trace statistics of Johansen test of cointegration propose three cointegration equations in to the VAR model at 5\% level of significance (Table 3). Probabilities of cointegration equations from None to At most 2 are significant at $5 \%$ and the null hypotheses are rejected. P value of At most 3 is insignificant as the $P$ value is 0.8573. This indicates that there are 3 cointegration equations in the model. Therefore, results provided by trace statistics revealed that there is a long run equilibrium relationship among non-stationary variables and there exist precisely three (3) cointegrating equations in the estimated model. Table 4 presents the long run model of cointegration and the correspondent long run coefficient of each independent variable as all the four (4) variables (including dependent variable) are cointegrated.

Two Debt variables (DD, ED) and the education (EDU) have obtained negative coefficients. They say that in the long run there is a negative influence on

Table 2. Information criteria results.

\begin{tabular}{|c|c|c|c|c|c|c|}
\hline Lag & $\log L$ & LR & FPE & AIC & SC & HQ \\
\hline 0 & -375.0981 & NA & 111771.2 & 22.97564 & 23.15704 & 23.03668 \\
\hline 1 & -164.3427 & 357.6456 & 0.843816 & 11.17228 & $12.07926^{*}$ & $11.47745^{\star}$ \\
\hline 2 & -152.9286 & 16.60231 & 1.168070 & 11.45022 & 13.08277 & 11.99952 \\
\hline 3 & -128.1870 & $29.98981^{*}$ & $0.778050^{*}$ & $10.92042^{*}$ & 13.27856 & 11.71386 \\
\hline
\end{tabular}

Note: ${ }^{*}$ indicates the number of lag length.

Table 3. Cointegration results.

\begin{tabular}{|c|c|c|c|c|}
\hline Hypothesized & & Trace & 0.05 & \\
\hline No. of CE(s) & Eigenvalue & Statistic & Critical value & Prob. ${ }^{* *}$ \\
\hline None ${ }^{\star * *}$ & 0.680013 & 72.19233 & 47.85613 & 0.0001 \\
\hline At most $1^{* * *}$ & 0.454941 & 35.72918 & 29.79707 & 0.0092 \\
\hline At most $2^{\star *}$ & 0.398703 & 16.30964 & 15.49471 & 0.0376 \\
\hline At most 3 & 0.001009 & 0.032316 & 3.841466 & 0.8573 \\
\hline
\end{tabular}

Note: ${ }^{* *}$ and ${ }^{* *}$ indicate statistically significant at $1 \%$ level and $5 \%$ level respectively. 
economic growth. However this long run equilibrium is still inconclusive because significance of long run association of the variables has not been estimated. Therefore, in order to evaluate the long run causality/association, Vector Error Correction Model is employed in Table 5 to the target model of the study (where lnGDP is the dependent variable).

\subsection{Results of Vector Error Correction Model (VECM)}

Probability of error correction term that is 0.039 with negative beta of -0.58 and

Table 4. Long run of coefficients.

\begin{tabular}{cccc}
\hline \multicolumn{4}{l}{ Normalized cointegrating coefficients (standard error in parentheses) } \\
\hline GDP & DD & ED & EDU \\
\hline \multirow{2}{*}{1.000000} & -0.560330 & -0.122317 & $-7.45 \mathrm{E}-06$ \\
& $(0.03155)$ & $(0.03292)$ & $(5.5 \mathrm{E}-07)$ \\
\hline
\end{tabular}

Table 5. VECM regression results.

\begin{tabular}{|c|c|c|c|c|}
\hline \multicolumn{5}{|l|}{ Dependent variable: $\mathrm{D}(\mathrm{GDP})$} \\
\hline & Coefficient & Std. error & $\mathrm{t}$-Statistic & Prob. \\
\hline Error correction term ${ }^{\star *}$ & -0.582624 & 0.259620 & -2.244145 & 0.0393 \\
\hline $\operatorname{Gdp}(-1)^{*}$ & 0.319841 & 0.180720 & 1.769815 & 0.0958 \\
\hline $\operatorname{Gdp}(-2)$ & 0.034285 & 0.177651 & 0.192988 & 0.8494 \\
\hline $\operatorname{Gdp}(-3)$ & 0.254077 & 0.151937 & 1.672244 & 0.1139 \\
\hline $\mathrm{DD}(-1)$ & -0.096492 & 0.148709 & -0.648865 & 0.5256 \\
\hline $\mathrm{DD}(-2)$ & 0.147769 & 0.162885 & 0.907196 & 0.3778 \\
\hline $\mathrm{DD}(-3)$ & 0.061271 & 0.126894 & 0.482854 & 0.6357 \\
\hline $\operatorname{ED}(-1)$ & -0.040151 & 0.218625 & -0.183653 & 0.8566 \\
\hline $\operatorname{ED}(-2)^{\star \star}$ & -0.399007 & 0.182815 & -2.182565 & 0.0443 \\
\hline $\mathrm{ED}(-3)$ & 0.063040 & 0.209277 & 0.301226 & 0.7671 \\
\hline Edu $(-1)$ & $3.61 \mathrm{E}-06$ & $2.90 \mathrm{E}-06$ & 1.247008 & 0.2303 \\
\hline Edu $(-2)$ & $-2.98 \mathrm{E}-06$ & $1.94 \mathrm{E}-06$ & -1.539036 & 0.1433 \\
\hline Edu $(-3)$ & $1.16 \mathrm{E}-06$ & $2.05 \mathrm{E}-06$ & 0.566739 & 0.5788 \\
\hline Constant & 0.084719 & 0.129104 & 0.656207 & 0.5210 \\
\hline R-squared & 0.749128 & \multicolumn{2}{|c|}{ Mean dependent var } & 0.137969 \\
\hline Adjusted R-squared & 0.513935 & \multicolumn{2}{|c|}{ S.D. dependent var } & 0.050610 \\
\hline S.E. of regression & 0.035285 & \multicolumn{2}{|c|}{ Akaike info criterion } & -3.543876 \\
\hline Sum squared resid & 0.019920 & \multicolumn{2}{|c|}{ Schwarz criterion } & -2.811008 \\
\hline Log likelihood & 72.70201 & \multicolumn{2}{|c|}{ Hannan-Quinn criter. } & -3.300951 \\
\hline F-statistic & 3.185165 & \multicolumn{2}{|c|}{ Durbin-Watson stat } & 2.311027 \\
\hline Prob (F-statistic) & 0.013774 & & & \\
\hline
\end{tabular}

Note: ${ }^{* *}$ and $^{*}$ indicate statistically significant at $5 \%$ level and $10 \%$ level respectively. 
it is significant at 5\% level (Table 5). This indicates that there is a long run association between GDP and public debt. When there is a shock in the previous year, $58 \%$ of disequilibrium is adjusted in the current year to the long run equilibrium.

Other coefficients represent the short run impact of lagged periods. In the short run two periods lagged of external debt is significant at $5 \%$ and there is a short run impact on economic growth. This indicates that $1 \%$ change of external debt has a negative effect on economic growth by $0.39 \%$. One period lagged of Gdp has a positive impact on economic growth at $10 \%$. Domestic debt and educational expenditure are not statistically significant for short period of times. Therefore, it can be said that the impact of changes in domestic debt and education are not transitory even though it affects economic growth in the long run as a permanent effect.

\subsection{Diagnostic Tests}

Probability of observed R-squared is 0.58 and the result is insignificant (Table 6). This says that variance of residual is constant and the model is not having heteroscedasticity problem. Therefore, model is appropriate.

Correlogram Q statistics indicate that all the probabilities are insignificant and no serial correlation or auto correlation in the residuals (Table 7). Therefore, the model is appropriate and results are valid.

Probability of Jarque-Bera test statistics is 0.805 and result is insignificant (Figure 2). This indicates that residuals are normally distributed with zero mean and the regression model is highly valid.

\section{Conclusions}

This study examines the impact of public debt on economic growth in Sri Lanka over the period of 1977 to 2012. Public debt is classified as public domestic debt and public external debt and their impacts towards economic growth in long run. For this purpose, the study adapted Johansen test of cointegration to estimate the long run impact followed by Vector Error Correction Model. Finally Error Correction Term was used to capture the speed of adjustment.

In addressing research objective, the study finds domestic debt, external debt and educational expenditure significantly affect economic growth in long run. As the policy implication, the results of the study are providing strategic information for the government in making policy decisions with regard to borrowing

Table 6. Heteroscedasticity test results.

\begin{tabular}{cccc}
\hline \multicolumn{4}{c}{ Heteroskedasticity test: Breusch-Pagan-Godfrey } \\
\hline F-statistic & 0.743784 & Prob. F $(16,15)$ & 0.7185 \\
\hline Obs ${ }^{\star}$ R-squared & 14.15649 & Prob. Chi-Square (16) & 0.5871 \\
Scaled explained SS & 3.074459 & Prob. Chi-Square (16) & 0.9998 \\
\hline
\end{tabular}


Table 7. Serial correlation test results.

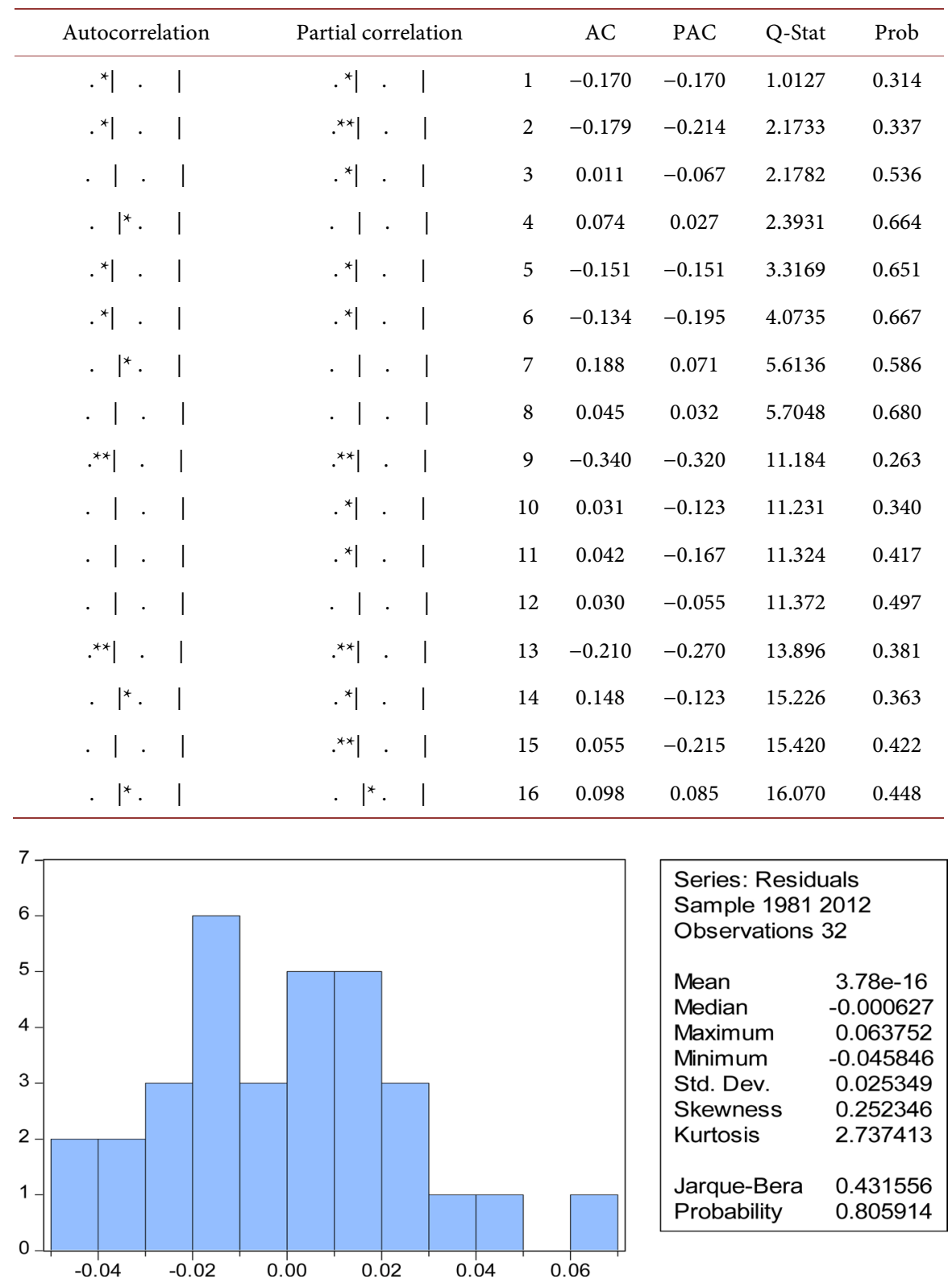

Figure 2. Probability of Jarque-Bera test statistics and result.

debt. The government of Sri Lanka needs to pay attention to the financing budget deficit by properly maintaining the threshold for debt as a proportion of GDP. Foreign and domestic borrowings will influence on economic growth in the long run but threshold for debt is a factor to be evaluated in financial decisions. Public debt and economic growth gained must be paid attention over the time in budgetary decision making. This is vital to lead an appropriate "Debt-to-GDP" ratio; otherwise debt will drag economic growth negatively.

From the policy prospective, it is recommended to refrain from adverse effects of external debt and public domestic debt on economic growth. The negative effect on economic growth is more severe. As foreign exchange reserves are very 
important for paying back external debt; the revenue generated from export can help Sri Lanka to overcome the issue. Therefore, export diversification strategies and value added export must be strongly promoted. Also good relations with other countries to reduce trade barriers must be encouraged. At the same time, value of Sri Lanka Rupee in foreign exchange market should be protected because currency devaluation strategy to enhance exports has not been helpful against competitive devaluations. As external and domestic debt have negative impact on GDP, policy makers' heavy reliance of debt to finance fiscal deficit must be discouraged because there is dire need to stimulate revenue.

\section{References}

[1] Soludo, C.C. (2003) The Debt Trap in Nigeria: Towards a Sustainable Debt Strategy. Africa World Press, New Jersey.

[2] Akram, N. (2011) Impact of Public Debt on the Economic Growth of Pakistan. The Pakistan Development Review, 50, 599-615.

[3] Fonseka, A.T. and Ranasinghe, S.S. (2007) Sustainability of Sri Lanka's Public Debt. Sri Lankan Journal of Management, 12, 185-212.

[4] Cecchetti, S.G., Mohanty, M.S. and Zampolli, F. (2011) The Real Effects of Debt. BIS Working Papers No: 352. http://www.bis.org/publ/work 352.htm

[5] Pathberiya, P. and Wijeweera, A. (2005) An Overview of the External Debt Situation in Sri Lanka. UNEAC Asia Papers, 1-10.

[6] Bernheim, B.D. (1989) A Neoclassical Perspective on Budget Deficits. Journal of Economic Perspectives, 3, 55-72. https://doi.org/10.1257/jep.3.2.55

[7] Barro, R.J. (1974) Are Government Bonds Net Wealth? Journal of Political Economy, 82, 1095-1117. https://doi.org/10.1086/260266

[8] Buchanan, J.M. (1976) Barro on the Ricardian Equivalance Theorem.

[9] Chowdhury, A.R. (2001) External Debt and Growth in Developing Countries; A Sensitivity and Causal Analysis. World Institute for Development Economics (UNU-WIDER) 2001/95.

[10] Paudel, R.C. and Perera, N. (2009) Foreign Debt, Trade Openness, Labor Force and Economic Growth: Evidence from Sri Lanka. Journal of Applied Economics, 8, 57-64.

[11] Egbetunde, T. (2012) Public Debt and Economic Growth in Nigeria: Evidence from Granger Causality. American Journal of Economics, 2, 101-106. https://doi.org/10.5923/j.economics.20120206.02

[12] Shah, M.H. and Pervin, S. (2012) External Public Debt and Economic Growth: Empirical Evidence from Bangladesh, 1974 to 2010. Academic Research International, 3, 508-515.

[13] Barik, A. (2012) Government Debt and Economic Growth in India. Centre for Economic Studies and Planning.

[14] Reinhart, C.M., Rogoff, K.S. and Savastano, M.A. (2003) Debt Intolerance. Nber Working Paper Series, 1-77. https://doi.org/10.3386/w9908

[15] Akhtar, T. and Hassan, H. (2012) Public Debt Burden and Economic Growth of Bangladesh: A VAR Approach. 1-10. https://doi.org/10.2139/ssrn.2152592

[16] Eflhimiadis, T. and Tsintzos, P. (2012) The Internal-External Debt Ratio and Economic Growth. Economics Bulletin, 32, 941-951. 
[17] Granger, C. and Newbold, P. (1974) Spurious Regressions in Econometrics. Journal of Econometrics, 2, 111-120. https://doi.org/10.1016/0304-4076(74)90034-7

[18] Ali, R. and Mustafa, U. (2011) External Debt Accumulation and Its Impact on Economic Growth in Pakistan. The Pakistan Development Review, 51, 79-95.

[19] Cunningham, R. T. (1993) The Effects of Debt Burden on Economic Growth in Heavily Indebted Developing Nations. Journal of Economic Development, 18, 115-126.

[20] Karagol, E. (2002) The Causality Analysis of External Debt Service and GNP: The Case of Turkey. Central Bank Review, 2, 39-64.

[21] Wijeweera, A., Dollery, B. and Pathberiya, P. (2005) Economic Growth and External Debt Servicing: A cointegration Analysis of Sri Lanka, 1952 to 2002. Working Paper Series of Economics, University of New England, School of Economics.

[22] Atique, R. and Malik, K. (2012) Impact of Domestic and External Debt on the Economic Growth of Pakistan. World Applied Sciences Journal, 20, 120-129.

[23] Engle, R.F. and Granger, C.W. (1987) Co-Integration and Error Correction: Representation, Estimation, and Testing. Econometrica, 55, 251-276. https://doi.org/10.2307/1913236

[24] Johansen, S. and Juselius, K. (1990) Maximum Likelihood Estimation and Inference on Cointegration-With Applications to the Demand for Money. Oxford Bulletin of Economics and Statistics, 52, 169-207.

https://doi.org/10.1111/j.1468-0084.1990.mp52002003.x 